IJOEM

16,5

\section{6}

\title{
Editorial statement and research ideas for behavioral financial economics in the emerging market
}

Behavioral financial economics is a major milestone in the development of modern theory in financial economics, especially for the emerging market because many studies have been showing that there are some anomalies and paradoxes and many financial phenomena, like Internet bubble and financial crises (Shiller, 2000), in financial economics, especially for the emerging market that traditional theories in financial economics cannot explain. For example, using the traditional theory of market efficiency, it is impossible for investors to outperform the market because the market efficiency theory (Markowitz, 1991) claims that stocks are always trading at their fair values, and all the information relevant to stock prices has been reflected in stock prices and is quickly priced in the market, concluding that price movement follows a random walk model. However, in reality, some investors do outperform other investors and perform better than the market, and most, if not all, stock prices do not follow any random walk model. Nonetheless, many empirical findings have shown that some anomalies and paradoxes, for example, the diversification puzzle, excess volatility, herd behavior, under-reaction and overreaction, could persist, and other anomalies, for example, calendar anomalies, may disappear, and some may reappear later on.

To find reasons or obtain solutions for some anomalies and paradoxes that traditional theories in financial economics cannot explain, scholars incorporate ideas and concepts from both psychology and sociology with financial economics (Selden, 1912). To do so, scholars could first establish some theoretical models in behavioral financial economics, develop the corresponding statistics and conduct simulations to show that their statistics are efficient and powerful. Thereafter, academics and practitioners could then use the models and statistics to examine whether the anomalies and paradoxes could still hold empirically and analyze important issues in traditional financial economics. They could also use the models and statistics to analyze some interesting and important empirical problems in financial economics.

There are many areas in establishing new theories for behavioral financial economics. For example, Bentham (1780) develops the principle of utility to achieve the greatest amount of happiness and the minimum amount of pain. Academics could follow this direction to develop new theories on different utilities, for example, risk aversion (Bernoulli, 1738), risk-loving (Wong, 2007), skewness-loving (Astebro et al., 2015), prospect theory (Kahneman and Tversky, 1979), reverse S-shaped utility functions (Wong and Chan, 2008), disappointment aversion (Guo et al., 2021), regret aversion (Guo et al., 2015), loss aversion (Tversky and Kahneman, 1991), etc. One could work on bounded rationality (Simon, 1982) for individuals to make decisions when facing restrictions on rationality, cognitive limitations and time and apply nudge theory (Cai, 2020) for investors to get their desired results to be better off and for regulators to make better ethical decisions. One could develop theories in stochastic dominance (Guo and Wong, 2016), almost stochastic dominance (Guo et al., 2014) and

International Journal of Emerging Markets

Vol. 16 No. 5,2021

pp. $946-951$

(c) Emerald Publishing Limited 1746-8809

DOI 10.1108/IJOEM-07-2021-991
The author would like to thank Robert B. Miller and Howard E. Thompson for their continuous guidance and encouragement. For financial and research support, the author acknowledges Asia University, China Medical University Hospital, the Hang Seng University of Hong Kong, the Research Grants Council of Hong Kong (project number 12500915) and the Ministry of Science and Technology (MOST, Project Numbers 106-2410-H-468-002 and 107-2410-H-468-002-MY3), Taiwan. 
different risk measures, for example, Farinelli-Tibiletti ratio (Guo et al., 2019) and Kappa ratio (Niu et al., 2017), to compare different assets and portfolios for different types of individuals. Other theories in behavioral financial economics include arbitrage opportunity (Guo et al., 2017), portfolio optimization (Bai et al., 2009), background risk (Guo et al., 2018), diversification (Egozcue and Wong, 2010), segregating or integrating models (Egozcue et al., 2014), cost of capital (Wong and Chan, 2004), technical analysis and trading strategies (Chan et al., 2014), money management and asset valuation (Brown and Cliff, 2005), financial crisis (Hassan et al., 2021), contagion (Wan and Wong, 2001), cointegration and causality (Bai et al., 2011), wavelet (Raza et al., 2016), artificial intelligence (Russell and Norvig, 2002), copulas (Egozcue et al., 2013) and many others.

One main area in behavioral financial economics is to study anomalies, paradoxes and puzzles, including equity premium puzzle (Mehra and Prescott, 1985), risk-free rate puzzle (Weil, 1989), intertemporal choice (Loewenstein and Thaler, 1989), small-firm effect (Roll, 1981), neglected firm effect (Arbel and Strebel, 1982), herd behavior (Batmunkh et al., 2020), calendar anomalies (Lean et al., 2007), Gambler's fallacy (Clotfelter and Cookth, 1993), the diversification puzzle, excess volatility, under-reaction and overreaction. Scholars could develop theories to explain anomalies. Some explain anomalies by using the concept of mispricing (Lakonishok et al., 1994) from a benchmark model of asset prices, for example, the capital asset pricing model (CAPM), Fama-French three-factor model, Fama-FrenchCarhart four-factor model, Stambaugh and Yuan's four-factor model, Fama-French fivefactor model, Merton's intertemporal CAPM theory, consumption CAPM theory, etc. while some, for example, Fama and French (1993), explain anomalies by using the idea of unmeasured risk. One could use different heuristics, for example, conservative and representative heuristics (Lam et al., 2010) and satisficing heuristics (Papi, 2012), to explain anomalies. Scholars could also use other ideas of behavioral financial economics, for example, herd behavior (Batmunkh et al., 2020) and framing effects (Levin et al., 1998), and other cognitive effects to explain the decisions made by different investors.

In order to develop new theories and contribute to the literature in behavioral financial economics with applications, the special issue on Behavioral Financial Economics in Emerging Markets edited by Ephraim Clark, João Paulo Torre Vieito, Aviral Kumar Tiwari and Wing-Keung Wong is devoted to advancements in the development on behavioral financial economics in emerging markets in 2020. In this special issue, we invite academics and practitioners to submit their research or review manuscripts that fit in the spirit and scope of our special issue. The special issue of Behavioral Financial Economics in Emerging Markets has published five papers including Hong et al. (2021), Lo et al. (2021), Shen et al. (2021), Wong (2021) and Yeap et al. (2021).

Among them, Hong et al. (2021) extend Figlewski's (1984) margin buying model by developing a new margin setting method and apply the model to compute margin levels for China. They find that under different changing market conditions, the margins will go down when the corresponding asset prices go up and vice versa. They also find that both costs of margin buying from investors' perspectives and the operational costs from brokers' perspectives adopted by stock exchanges are significantly higher than those incurred by the margin system.

Using a dynamic Copula-CoVaR approach to examine the daily risk spillover between London and Shanghai futures markets, Shen et al. (2021) find that both squared Euclidean distance test and kernel estimation method determine their optimal Copula functions and marginal distribution, and the impact of the risk spillover from the Shanghai Metal Exchange on the corresponding London Exchange is less significant than those in the opposite direction. They also find that the degree of risk spillover for both zinc and copper is more significant when exerted from the London Metal Exchange to the corresponding Shanghai Exchange when depressed in the London market. In addition, they find evidence that the 
IJOEM

16,5

\section{8}

dynamic correlation between London and Shanghai future markets depends on the global economy.

By using the stakeholder perspective, including firm age, a corporate credit risk index, corporate financial performance and an evaluation of a firm's corporate governance, Lo et al. (2021) first develop a new sustainability index. Thereafter, they employ both regression and fuzzy set qualitative comparative analysis (FsQCA) to obtain several models to optimize firms' sustainability. The findings by using both regression and FsQCA conclude that all the factors used in their paper have significant impacts on the sustainability of firms. Their FsQCA solutions imply that the internal resources and capabilities of a firm and the fit of combinations of institutional factors can be used to explain the firms' sustainability.

Examining the market risk, the dependence structure and the joint distribution of the portfolio formed by currency exchange rates and the extreme events through the extreme value theory, Yeap et al. (2021) find that the marginal returns of CNY, USD, SGD, THB and JPY follow the Bayesian GARCH(1,1) model with Student's $t$ errors and show that Student's $t$ and Gumbel are the best elliptical and Archimedean copulas, respectively, for CNY, USD, SGD, THB and JPY. Last, Wong (2021) discusses some research ideas and provides an editorial statement in behavioral financial economics.

\section{Wing-Keung Wong}

\section{References}

Arbel, A. and Strebel, P. (1982), "The neglected and small firm effects", Financial Review, Vol. 17 No. 4, pp. 201-218.

Åstebro, T., Mata, J. and Santos-Pinto, L. (2015), "Skewness seeking: risk loving, optimism or overweighting of small probabilities?”, Theory and Decision, Vol. 78, pp. 189-208.

Bai, Z.D., Liu, H.X. and Wong, W.K. (2009), "Enhancement of the applicability of Markowitz's portfolio optimization by utilizing random matrix theory", Mathematical Finance, Vol. 19 No. 4, pp. 639-667.

Bai, Z.D., Li, H., Wong, W.K. and Zhang, B.Z. (2011), "Multivariate causality tests with simulation and application", Statistics and Probability Letters, Vol. 81 No. 8, pp. 1063-1071.

Batmunkh, M.-U., Choijil, E., Vieito, J.P., Espinosa-Méndez, C. and Wong, W.K. (2020), "Does herding behavior exist in the Mongolian stock market”, Pacific-Basin Finance Journal, Vol. 62, p. 101352, doi: 10.1016/j.pacfin.2020.101352.

Bentham, J. (1780), An Introduction to the Principles of Morals and Legislation.

Bernoulli, D. (1738), "Exposition of a new theory on the measurement of risk", translated by Dr. Louise Sommer. (1954), Econometrica, Vol. 22 No. 1, pp. 22-36.

Brown, G.W. and Cliff, M.T. (2005), "Investor sentiment and asset valuation", Journal of Business, Vol. 78 No. 2, pp. 405-440.

Cai, C.W. (2020), "Nudging the financial market? A review of the nudge theory", Accounting and Finance, Vol. 60 No. 4, pp. 3341-3365.

Chan, R.H., Lee, S.T.H. and Wong, W.K. (2014), Technical Analysis and Financial Asset Forecasting: From Simple Tools to Advanced Techniques, World Scientific Publishing Company.

Clotfelter, C.T. and Cookth, P.J. (1993), "The "Gambler's Fallacy" in lottery play”, Management Science, Vol. 39 No. 12, pp. 1521-1525.

Egozcue, M. and Wong, W.K. (2010), "Gains from diversification: a majorization and stochastic dominance approach", European Journal of Operational Research, Vol. 200 No. 3, pp. 893-900.

Egozcue, M., Fuentes García, F., Wong, W.K. and Zitikis, R. (2013), "Convex combinations of quadrant dependent copulas", Applied Mathematics Letters, Vol. 26 No. 2, pp. 249-251. 
Egozcue, M., Massoni, S., Wong, W.K. and Zitikis, R. (2014), "Integration-segregation decisions under general value functions: 'Create your own bundle - choose 1, 2, or all 3!'”, IMA Journal of Management Mathematics, Vol. 25 No. 1, pp. 57-72.

Fama, E.F. and French, K.R. (1993), "Common risk factors in the return on stocks and bonds", Journal of Financial Economics, Vol. 33, pp. 3-56.

Figlewski, S. (1984), "Margins and market integrity: margin setting for stock index futures and options", Journal of Futures Markets, Vol. 4, pp. 385-416.

Guo, X. and Wong, W.K. (2016), "Multivariate stochastic dominance for risk averters and risk seekers", RAIRO - Operations Research, Vol. 50 No. 3, pp. 575-586.

Guo, X., Post, T., Wong, W.K. and Zhu, L.X. (2014), "Moment conditions for almost stochastic dominance", Economics Letters, Vol. 124 No. 2, pp. 163-167.

Guo, X., Wong, W.K., Xu, Q.F. and Zhu, L.X. (2015), "Production and hedging decisions under regret aversion”, Economic Modelling, Vol. 51, pp. 153-158.

Guo, X., Jiang, X.J. and Wong, W.K. (2017), "Stochastic dominance and omega ratio: measures to examine market efficiency", Arbitrage Opportunity, and Anomaly, Economies, Vol. 5 No. 4, p. 38.

Guo, X., Wagener, A., Wong, W.K. and Zhu, L.X. (2018), "The two-moment decision model with additive risks", Risk Management, Vol. 20 No. 1, pp. 77-94.

Guo, X., Niu, C.Z. and Wong, W.K. (2019), "Farinelli and Tibiletti ratio and stochastic dominance", Risk Management, Vol. 21 No. 3, pp. 201-213.

Guo, X., Egozcue, M. and Wong, W.K. (2021), "Production theory under price uncertainty for firms with disappointment aversion”, International Journal of Production Research, Vol. 59 No. 8, pp. 2392-2405.

Hassan, K., Hoque, A., Gasbarro, D. and Wong, W.K. (2021), "Are Islamic stocks immune from financial crises? Evidence from contagion tests", International Review of Economics and Finance, forthcoming.

Hong, H., Lee, C.-C. and Bian, Z. (2021), "Setting margins for margin buying in China: balancing the tradeoff between liquidity and prudence”, International Journal of Emerging Markets, Vol. 16 No. 5, pp. 885-908.

Kahneman, D. and Tversky, A. (1979), "Prospect theory: an analysis of decision under risk", Econometrica, Vol. 47, pp. 263-291.

Lakonishok, J., Shleifer, A. and Vishny, R.W. (1994), "Contrarian investment, extrapolation, and risk", Journal of Finance, Vol. 49 No. 5, pp. 1541-1578.

Lam, K., Liu, T.S. and Wong, W.K. (2010), "A pseudo-Bayesian model in financial decision making with implications to market volatility, under- and overreaction", European Journal of Operational Research, Vol. 203 No. 1, pp. 166-175.

Lean, H.H., Smyth, R. and Wong, W.K. (2007), "Revisiting calendar anomalies in Asian stock markets using a stochastic dominance approach", Journal of Multinational Financial Management, Vol. 17 No. 2, pp. 125-141.

Levin, I.P., Schreiber, J.L. and Gaeth, G.J. (1998), "All frames are not created equal: a typology and critical analysis of framing effects", Organizational Behavior and Human Decision Processes, Vol. 76 No. 2, pp. 149-188.

Lo, F.Y., Wong, W.K. and Geovani, J. (2021), "Optimal combinations of factors influencing the sustainability of Taiwanese firms", International Journal of Emerging Markets, Vol. 16 No. 5, pp. 909-928.

Loewenstein, G. and Thaler, R.H. (1989), “Anomalies: intertemporal choice”, Journal of Economic Perspectives, Vol. 3 No. 4, pp. 181-193.

Markowitz, H.M. (1991), "Foundations of portfolio theory", Journal of Finance, Vol. 46 No. 2, pp. 469-477.

Mehra, R. and Prescott, E.C. (1985), “The equity premium: a puzzle”, Journal of Monetary Economics, Vol. 15 No. 2, pp. 145-161. 
IJOEM

16,5

Niu, C.Z., Wong, W.K. and Xu, Q.F. (2017), "Kappa ratios and (Higher-Order) stochastic dominance", Risk Management, Vol. 19 No. 3, pp. 245-253.

Papi, M. (2012), "Satisficing choice procedures", Journal of Economic Behavior and Organization, Vol. 84 No. 1, pp. 451-462.

Raza, S.A., Sharif, A., Wong, W.K. and Karim, M.Z.A. (2016), "Tourism development and environmental degradation in United States: evidence from wavelet based analysis", Current Issues in Tourism, Vol. 2016, pp. 1-23.

Roll, R. (1981), “A possible explanation of the small firm effect”, Journal of Finance, Vol. 36 No. 4, pp. 879-888.

Russell, S. and Norvig, P. (2002), Artificial Intelligence: A Modern Approach.

Selden, G.C. (1912), Psychology of the Stock Market.

Shen, H., Tang, Y., Xing, Y. and Ng, P. (2021), "Examining the evidence of risk spillover between Shanghai and London non-ferrous futures markets: a dynamic Copula-CoVaR approach", International Journal of Emerging Markets, Vol. 16 No. 5, pp. 929-945.

Shiller, R.J. (2000), Irrational Exuberance, Princeton University Press, 1400824362.

Simon, H.A. (1982), Models of Bounded Rationality, Vols 1 and 2, MIT Press.

Tversky, A. and Kahneman, D. (1991), "Loss aversion in riskless choice: a reference-dependent model”, Quarterly Journal of Economics, Vol. 106 No. 4, pp. 1039-1061.

Wan, H.J. and Wong, W.K. (2001), "Contagion or inductance? Crisis 1997 reconsidered”, Japanese Economic Review, Vol. 52 No. 4, pp. 372-380.

Weil, P. (1989), "The equity premium puzzle and the risk-free rate puzzle", Journal of Monetary Economics, Vol. 24 No. 3, pp. 401-421.

Wong, W.K. (2007), "Stochastic dominance and mean-variance measures of profit and loss for business planning and investment", European Journal of Operational Research, Vol. 182 No. 2, pp. 829-843.

Wong, W.K. (2021), "Editorial statement and research ideas for behavioral financial economics in emerging market”, International Journal of Emerging Markets, Vol. 16 No. 5, pp. 946-951.

Wong, W.K. and Chan, R. (2004), "On the estimation of cost of capital and its reliability", Quantitative Finance, Vol. 4 No. 3, pp. 365-372.

Wong, W.K. and Chan, R. (2008), "Prospect and Markowitz stochastic dominance", Annals of Finance, Vol. 4 No. 1, pp. 105-129.

Yeap, X.W., Lean, H.H., Sampid, M.G. and Hasim, H.M. (2021), "Dependence structure and portfolio risk of Malaysia's foreign exchange rates: Bayesian GARCH-EVT-copula model”, International Journal of Emerging Markets, Vol. 16 No. 5, pp. 952-974.

\title{
Further reading
}

Smith, A. (1761), Theory of Moral Sentiments, 2nd ed., Strand \& Edinburgh.

\begin{abstract}
About the authors
Wing-Keung Wong obtained his Ph.D. from the University of Wisconsin-Madison, the USA with a major in Business Statistics (Statistics and Finance) and obtained his Bachelor degree from the Chinese University of Hong Kong, Hong Kong, with a major in Mathematics and a double minor in Economics and Statistics. Currently, he is a Chair Professor at the Department of Finance, Asia University. He was a Full Professor at the Department of Economics, Hong Kong Baptist University and Deputy Director at Risk Management Institute, National University of Singapore. Professor Wong appears in "Who's Who in the World" and gets Albert Nelson Marquis Lifetime Achievement Award 2017, Marquis Who's Who. His Erdos number is 3. He is ranked top 1\% by Social Science Research Network and in the list of top Taiwan economists and Asian economists and top economists by RePEc. He has published more than 400 papers, including papers published in some top journals. He has more than 10300 citations in Google
\end{abstract}


Scholar, more than 8,300 citations in Researchgate and more than 3,600 citations in Scopus. His h-index is 56, (40 since 2016) and i10-index is 216, (193 since 2016) by Google Scholar citation. He has been serving international academies, Government, society and universities, providing consultancy to several Government departments and corporations and giving lectures and seminars to several universities. For example, he has been serving as editor, guest leading editor, advisor, associate editor for some international journals, appointed as an advisor/member of various international associations/institutes, serving as a referee for many journals/conferences, supervising solely or jointly several overseas graduate students, appointed as an external reviewer and external examiner by other universities and invited by many universities/institutions to present papers or conduct seminars. 